\title{
小児期の下顎骨切除手術による顎顔面の変形について
}

\author{
伊藤昭彦・塩田重利* ・佐藤建夫* \\ 天笠光雄*·藤井英治*・篠塚恵造*
}

\section{Maxillofacial Deformity due to Mandibulectomy at the Childhood}

\author{
Akihiko Ito - Shigetoshi ShrodA* - Tateo SAto* \\ Teruo Amagasa* ${ }^{*}$ Eiji Fujir* ${ }^{*}$ Keizou Shinozuka*
}

\begin{abstract}
There are few reports about maxillofacial deformity and its developmental change caused by mandibulectomy at the childhood. The authors studied the maxillofacial deformity after mandibulectomy mainly by means of PA cephalogram.

The study objects included 8 patients who had undergone mandibulectomy in the age 5 to 15 years, at the First Department of Oral and Maxillofacial Surgery, Tokyo Medical and Dental University Hospital. Seven cases were diagnosed as ameloblastoma, and one as fibrosarcoma of the mandible.

PA cephalograms were taken at their adult ages, and analyzed. PO perpendicular was adopted as the standard of the midline of the face in analysis. Lateral cephalograms and Orthopantomograms were also used in analysis of the deformity as well as clinical findings. The results obtained are listed below.

1) The maxillofacial deformity after mandibulectomy was observed as midline deviation of the upper and lower jaws, hypoplasty of the mandibular ramus, extrusion of the upper molars,lotation and tilt to the disease site of the mandible, malocclusion and flattened angle of the mandible.
\end{abstract}

2) The degree of the maxillofacial deformity depended upon the operation method, the deformity was comparatively mild in the marginal resection cases. After hemimandibulectomy with conserving the lower border of the mandible till the mandibular angle, deformity had less than the conventional hemimandibulectomy without conserving the lower border of the mandible.

3 ) In the same operation group, the deformity of the patients who underwent the operation at a younger age had more severe deformity than those who underwent the operation at an older age.

From above result, we think the minimum operation is desirable at childhood. If the mandibular lesions were cyst or cystic ameloblastoma, marsupialization would be suitable in order to minimize the operation or to postpone the operation to an older age. If mandibulectomy must be done in childhood, it is important to conserve the condyle, the lower and posterior border of the mandible.

東京都立松沢病院檤科口膑外科

（主任：清田健司博士）

* 東京医科碀科大学隧学部第 1 口腔外科学教室 （主任：塩田重利教授）

Section of Dentistry and Oral Surgery, Tokyo Metropolitan Matsuzawa Hospital (Chief: Dr.
Kenji Kiyota)

* The First department of Oral and Maxillofacial Surgery, Tokyo Medical and Dental University, Faculty of Dentistry (Chief: Prof. Shigetoshi Shioda)

受付日：昭和 62 年 3 月 17 日 
Key words: mandibulectomy, maxillofacial deformity, PA cephalogram

\section{緒訔}

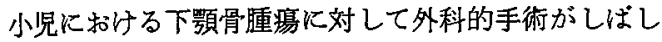
ば行われるが，この時期に行われる顎骨切除術は顎顔面 の発育に多大の影響を及ぼし，顎の発育完了後も靧顔面 の変形を残するのと考息られる。しかし，小見期におけ る下顎骨切除後の顎顔面の変形に関する詳細な研究報告 はいまだみられない，そこで，小韭期における下顎骨切 除手術が，面顔面の発育にいかなる影響を及ばすかを明 らかにするために，小児期下顎骨切除症例に対し頭部X 線規格写真分析を中心に，臨床的所見も併せて，買顔面 形態の変化について検討を行った。

\section{研 究 対 象}

対象症例は1965年から1980年の間に，東京医科歯科大 学歯学部第 1 口腔外科に沶いて下筫骨切除手術を受け た，15歳以下の 8 症例である（表 1 ）. 性別は男性 6 例, 女性 2 例, 手術時年齢は 5 歳 1 例, 10 歳 1 例, 14 歳 4 例，15歳 2 例である. 原疾患名はェナメル上皮腫 7 例, 線維肉腫 1 例である。手術術式により，I型は下顎関節 離断術を行い対側切断部位が下瀕骨体部で垂直になされ たもの (写真 1)，II 型は下䫇関節離断術を行い，下顠 骨下縁のみを下類角まで保存したもの(写直 2), そし て型は下䫇骨部分切除術（辺縁切除術）を行ったるの に分類した，それによると，対象症例の手術術式はI 型 3 例， II 型 1 例， III型 4 例である。これら症例の手術後
の観察期間は最低 2 年11か月, 最長 12 年 $11 か$ 月, 平均 9 年である。また，下買骨切除手術を実施した17紫以上の 患者 6 症例を対照群とし，また手術を行っていない健常 者24名とる比較検討した，対照群の下䫟骨切除症例 6 症 例の性別は男性 3 例，女性 3 例，手衍時年踰は17～30歳 で、原疾患は全例エナメル上皮尰であった，手術術式は

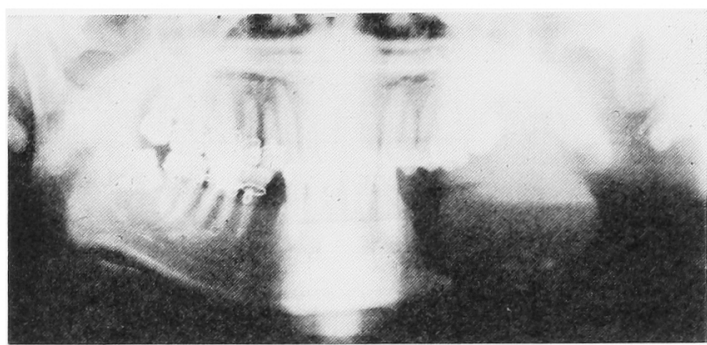

写真 1 症例 10 術直後のオルソパントモダラム (手術術式 I 型)

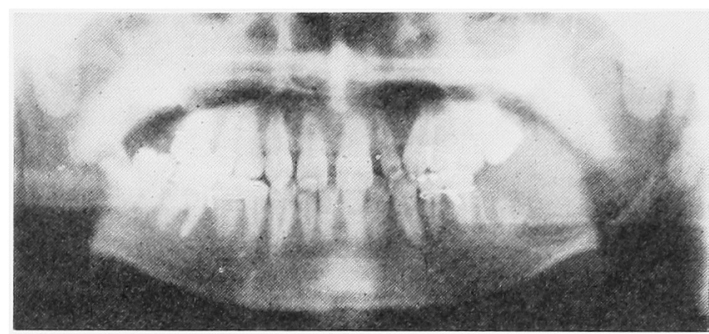

写真 2 症例 4 の術直後のオルソパントモグラム （手術術式 II 型）

表 1 対象应例

\begin{tabular}{|c|c|c|c|c|c|}
\hline 症例 & 性 & 手術時年槇 & 病名 & 手術術式 & 手術部位 \\
\hline 1 & 男 & 14 & エナメル上皮腫 & $\begin{array}{c}\text { 関節離断 } \\
(\mathrm{I} \text { 型 })\end{array}$ & 下頕枝～勾 \\
\hline 2 & 男 & 14 & エナメル上皮腫 & $\begin{array}{c}\text { 関節離断 } \\
(\mathrm{I} \text { 型 }\end{array}$ & 有一下顎枝 \\
\hline 3 & 男 & 15 & エナメル上皮電 & $\begin{array}{c}\text { 関節離断 } \\
(\mathrm{I} \text { 型 })\end{array}$ & $\sqrt{4} \sim$ 下顎㪔 \\
\hline 4 & 男 & 14 & エナメル上皮腫 & $\begin{array}{c}\text { 関節離断 } \\
\text { (II 型) }\end{array}$ & 6 $\sim$ 下顎枝 \\
\hline 5 & 女 & 5 & エナメル上皮腫 & $\begin{array}{c}\text { 部分切除 } \\
\text { (III型) }\end{array}$ & $\overline{6+1}$ \\
\hline 6 & 女 & 10 & 線維肉腫 & $\begin{array}{c}\text { 部分切除 } \\
\text { (III型) }\end{array}$ & |6〜下顎枝 \\
\hline 7 & 男 & 14 & エナメル上皮腫 & $\begin{array}{c}\text { 部分切除 } \\
\text { (III型) }\end{array}$ & 下顎枝 7 \\
\hline 8 & 男 & 15 & エナメル上皮腫 & $\begin{array}{c}\text { 部分切除 } \\
\text { (III型) }\end{array}$ & 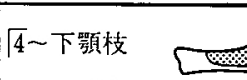 \\
\hline
\end{tabular}


表 2 対照症例

\begin{tabular}{|c|c|c|c|c|c|}
\hline 症例 & 性 & 手術時年剑 & 病名 & 手術術式 & 手術部位 \\
\hline 9 & 女 & 22 & エナメル上皮腫 & $\begin{array}{c}\text { 関節離断 } \\
\text { (II 型) }\end{array}$ & $\sqrt{5} \sim$ 下顎枝 \\
\hline 10 & 男 & 24 & エナメル上皮腫 & $\begin{array}{c}\text { 関節離断 } \\
(\mathrm{I} \text { 型 })\end{array}$ & $\sqrt{4} \sim$ 下顎枝 \\
\hline 11 & 男 & 30 & エナメル上皮腫 & $\begin{array}{c}\text { 関節離断 } \\
(\text { II 型) }\end{array}$ & 下顎枝－5 \\
\hline 12 & 女 & 17 & エナメル上皮腫 & $\begin{array}{c}\text { 部分切除 } \\
\text { (III型) }\end{array}$ & 下顎枝～司 \\
\hline 13 & 男 & 18 & エナメル上皮腫 & $\begin{array}{c}\text { 部分切除 } \\
\text { (III型) }\end{array}$ & 5 下顎枝 \\
\hline 14 & 女 & 23 & エナメル上皮腫 & $\begin{array}{c}\text { 部分切除 } \\
\text { (III型) }\end{array}$ & 「7〜下顎枝 \\
\hline
\end{tabular}

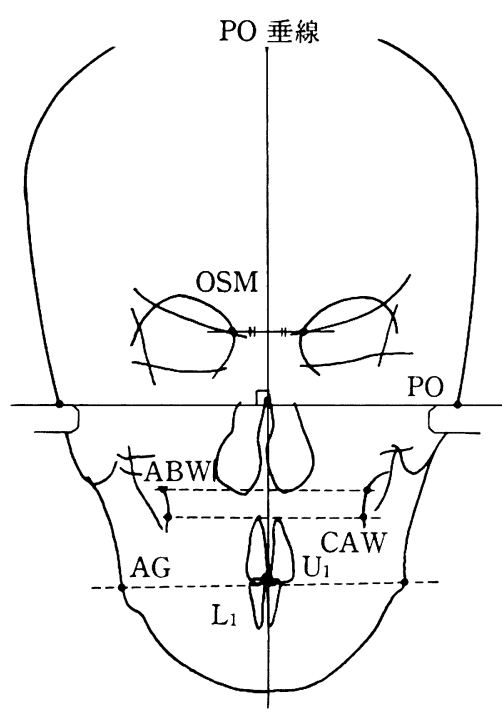

図 1 正貌頭部 $\mathbf{X}$ 線規格写真での基準点

I 型 1 例， II 型 2 例，III 型 3 例である（表 2 ）。健常者 群は顔面の変形を伴わない正常咬合を有する 24 37歳の 男性18名，女性 6 名，計24名である。

\section{研究方法}

対象症例および対照群に対し，靧発育の完了した時点 において，正貌と側貌の頭部X線規格写真を撮影した。 正貌写真の撮影は, 眼点指示器を使用して Frankfort 平 面に平行に行い，透写㘠を作成して計測を行った。図 1 に示すとおり，正中基準線と基準点の設定は，中後1,2) の研究に従い，正中基準線に PO 垂線を採用した。す なわち，左右の OSM を結んだ直線の中点を通り，左 右の $\mathrm{PO}$ を結んだ直線に垂直な直線である。計測上の 基準点には，表了に示すよらな，下顔面の各部分を代表
表 3 正貌頭部 X線規格写真での基準点の定義

PO (Porion) : Ear-rod 上の上縁の影像と側頭骨外 側の影像との交点.

OSM：前頭骨の眼窩上壁を形成する骨盤 (Orbital plate) の内側部の断面影像と蝶形骨小翼あるいは その延長部の前縁と前頭骨眼召部の後縁が鍣菌状 に稀合している部分の映像 (OS line) との交点.

$\mathrm{AG}: \mathrm{PO}$ から下顎角に向かって接線を引いた時の 接点.

U 1 : 上顎左右両㑡中切楼の近心切端隅角を結んだ 線の中点.

L 1 : 下顎左右両側中切画の近心切端隅角を結んだ 楾の中点.

$\mathrm{ABW}$ : ARI の下方から上顎第 1 大曰㳡附近に至る 上顎骨外側縁影像上の点で, MHW と CAWを 結ぶ直線からの最深点（上䫇歯槽基底部幅径点）

CAW : 上顎第 1 大曰幽ないし第 2 大曰歯の外側歯 頸部が同部蒾槽突起㮸槽縁と接する点（上顎橉列 弓幅径点)

する 5 種類の点を採用した. 5 種類の基準点は $\mathrm{ABW}$ (上 顎歯慒基底部幅径点), CAW (上額歯列弓幅径点), AG (下顎角点), U 1 (上顎中切歯点) およびL 1 （下頢中 切歯点）とした.

これら基準点の計測と分析については，各基準点の左 右の横幅径の和をそのまま使用しないで，近藤 ${ }^{3)}$ の研究 を参考にして，正中線からの左右基準点までの横幅径の 左右差を求めて分析の対象とした，AG では，健側と患 側のらち，より大きな横幅径を示した側を優位側と表示 した，数值の表示法として，健側の值には十の符号を， 患側の値にはーの符号をつけて区別した。 U 1 とL 1 で は，正中線を境にして基準点が存在する側を偏位してい る側と表現した。また，距離は $0.5 \mathrm{~mm}$ 単位で測定し 


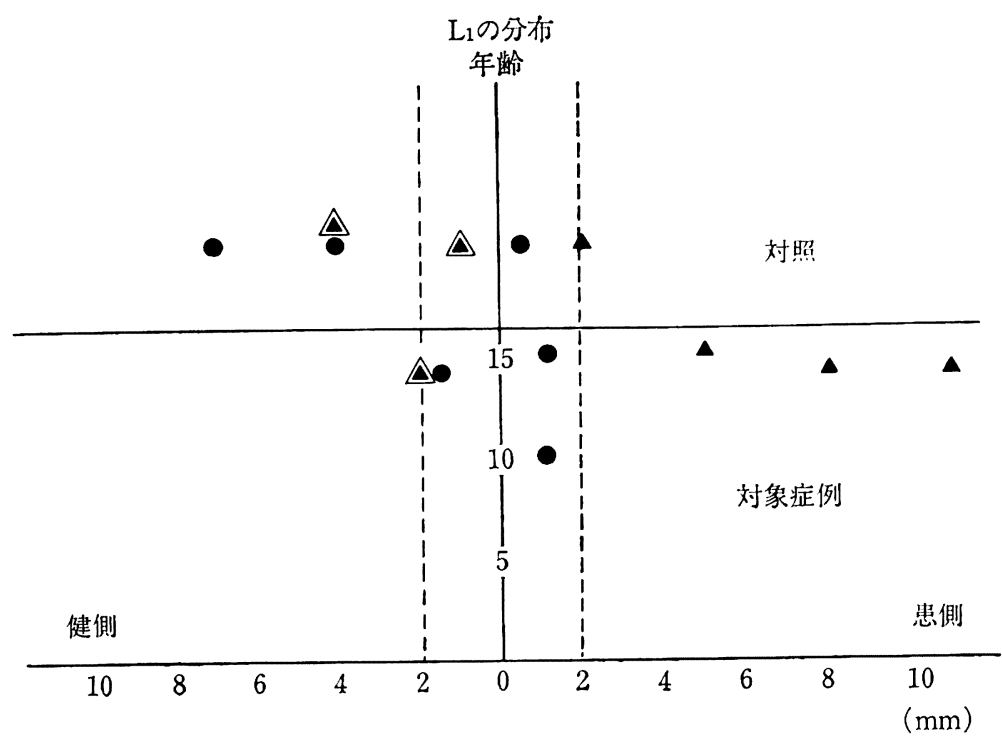

$\Delta$ I 型 $\triangle$ II 型 $\quad$ III型

図 2 正貌頭部X線規格写真分析によるL 1 の分布

た、 $\mathrm{ABW}, \mathrm{CAW}$ および $\mathrm{AG}$ の左右両側の点を結んだ 直線が Frankfort 平面となす角を求め，その角度をそ れぞれ $\mathrm{ABW}$ 角, $\mathrm{CAW}$ 角, $\mathrm{AG}$ 角とした。 健側の点 の方が，患側の点より Frankfort 平面に近い時，十の 角度で示し，逆の場合は一の角度で示した．角度の測定 には0. $5^{\circ}$ を最小の読み取りの単位とした。

側貌の頭部X線規格写真の分析は Downs 法とNorthwestern 法で行い, 基準データは飯塚ら゙)によった。

顎態模型は横田式の罘態模型調整器を使用して作製し た．靧態模型の上下買の崡の接触関係を示すために， Marcotte ${ }^{5)}$ の Occlusogram の方法に準じて，咬合面に 垂直な位置関係で撮影した等倍率のポジティブ・フィル ムを作成し，上下顎をかさね合わせて抬大器にかけてト レースし観察を行った。

\section{結果}

\section{1. 正貌頭部 $\mathbf{X}$ 線規格写真による分析}

1) 健常者群について

健常者群における正貌頭部X線規格写真の分析結果か ら得られた平均值と標準偏差を表 4 に示した。AG の左 右測定値に対して，左右の平均值の差の検定を $\mathrm{t}$ 検定に よって行ったが, 有意差は認められなかった（ $\mathrm{P}<1$ $\%$ ). $\mathrm{U} 1, \mathrm{~L} 1, \mathrm{ABW}$ 角, $\mathrm{CAW}$ 角, $\mathrm{AG}$ 角の偏位 について偏位量ゼロとした場合と比較して，平均値の差 の検定を行ったが，有意差は認められなかった（ $\mathrm{P}<1$ \%)，そこで，健常者の対照群に拈ける統計值からみて， 当研究の対照群の条件，正中基準線の選択，測定方法な

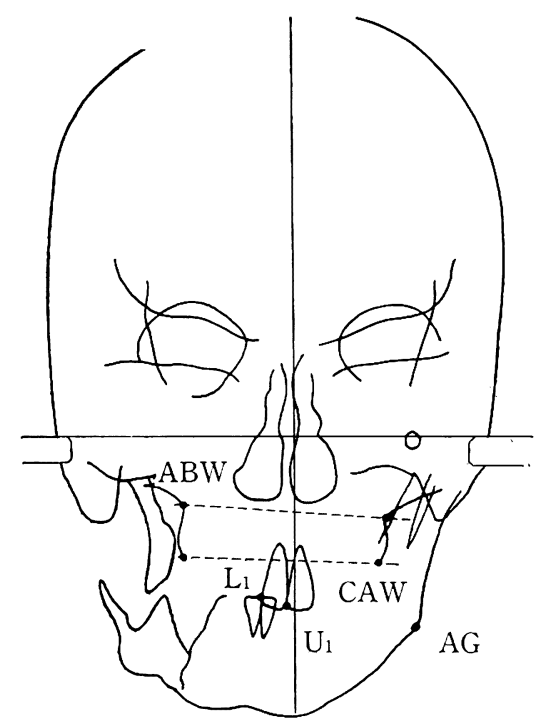

図 3 症例 1 の正貌頭部X線規格写真透写図

どは，妥当なものと考えられた，以下，対象症例におけ る分析結果を中心に対照と比較して示す

2）対象群および対照群について

L 1 について手術時年齢を縦軸に，偏位および優位の 数値を横軸にとり，図表に示した（図 2).（図4～8 9 いずれも同様の方法によった。十は健側偏位を，一は患 側偏位を示す。点線は健常者群での土 1 S.D. の範囲を 示す) 


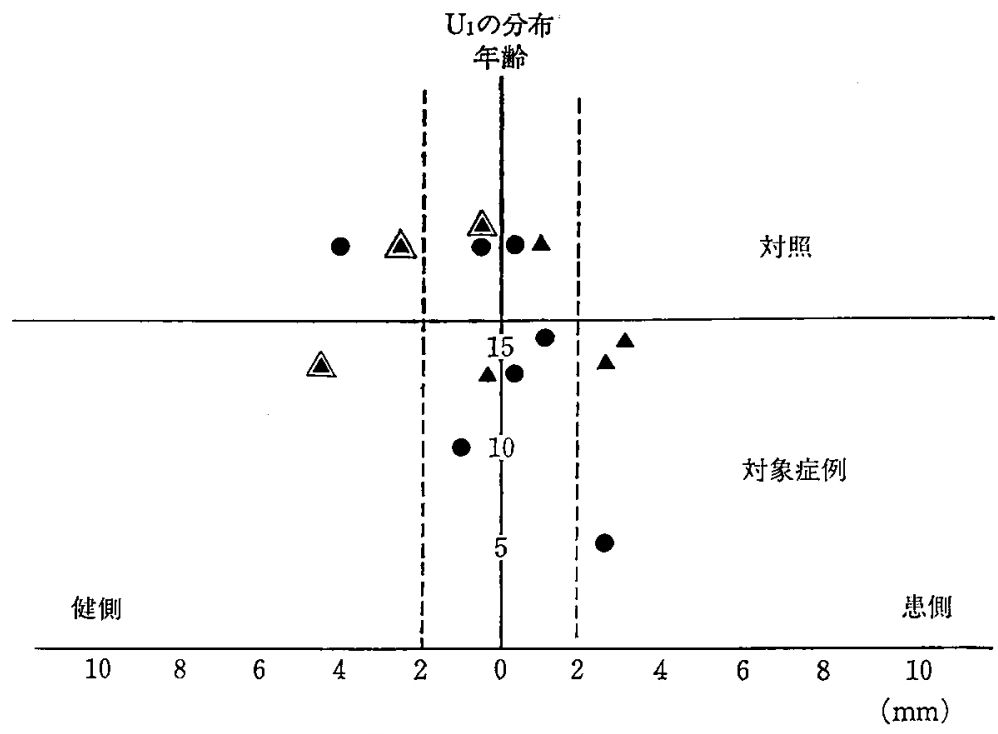

$\Delta I$ 型 $\triangle$ II型

図 4 正貌頭部X線規格写真分析に上るU 1 の分布

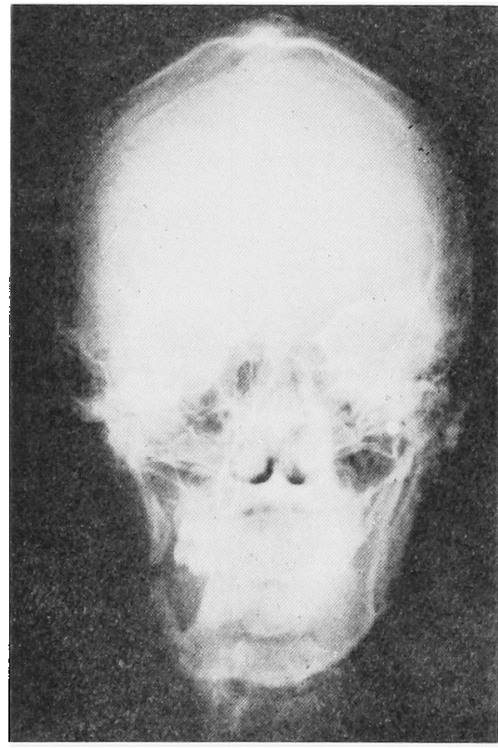

写真 3 症例 1 の正貌頭部X線規格写真

対象症例の L 1 の全体の分布は $+2 \sim-11 \mathrm{~mm}$ と健 常者群に比べ広い分布を示し，乙か子患側に偏ってい た. I 型ではー 5〜ー11 mm と，患側に偏って大きな 偏位を示吉傾向があった（写真了，図了）、II型では +2 mm と健側にわずかに偏位する傾向があった， II 型 では偏位は +1.5〜ー1 $\mathrm{mm}$ で偏位はほとんどなかっ た. 対照側の II 型では $+4 \sim+1 \mathrm{~mm}$ と健側に軽度に 偏位する傾向があり，同 III型では術前にすでに偏位がみ
表 4 健常者対照群の正貌頭部X線規格写真分析植

\begin{tabular}{|c|c|c|}
\hline & 平均 & 標準偏差 \\
\hline ABW & $+0.17 \mathrm{~mm}$ & 2.66 \\
\hline CAW & $+0.50 \mathrm{~mm}$ & 3.28 \\
\hline $\mathrm{AG}$ & $+0.79 \mathrm{~mm}$ & 4. 14 \\
\hline U 1 & $+0.50 \mathrm{~mm}$ & 1.92 \\
\hline L 1 & $+0.65 \mathrm{~mm}$ & 2.05 \\
\hline $\mathrm{ABW}$ 角 & $-0.31^{\circ}$ & 1.70 \\
\hline CAW 角 & $+0.29^{\circ}$ & 2.33 \\
\hline $\mathrm{AG}$ 角 & $+0.15^{\circ}$ & 1.84 \\
\hline
\end{tabular}

られた 1 例を除いて，健側に中程度偏位する傾向があっ た。

U 1 については，対象例全体の分布は+4.5 -3 mm と，健常者に比べてやや広い分布であり（図 4)，I型 では軽度に患側へ偏位する傾向を示し，II 型では反対に 健側に中程度の偏位を示した，対照群では型は軽度に 健側偏位を示し， II 型では術前からすでに偏位を示して いた 1 例を除いて，偏位はほとんどみられなかった．

AG については开型のみに設定できた（图 5). 対象 例では 5 歳時手術症例（症例 5 ）を除いて, AG の分布 は健常者群の 1 S.D. 範囲内に和さまっていたが, 明ら かに健側よりの㑯向を示した。 また，5藏時手術症例は + $7 \mathrm{~mm}$ と高度の健側優位を示した. 対照の II 型は術前 から AG が高度の健側優位を示した 1 例（症例 14）を 除いて，軽度に健側優位の傾向を示した。 


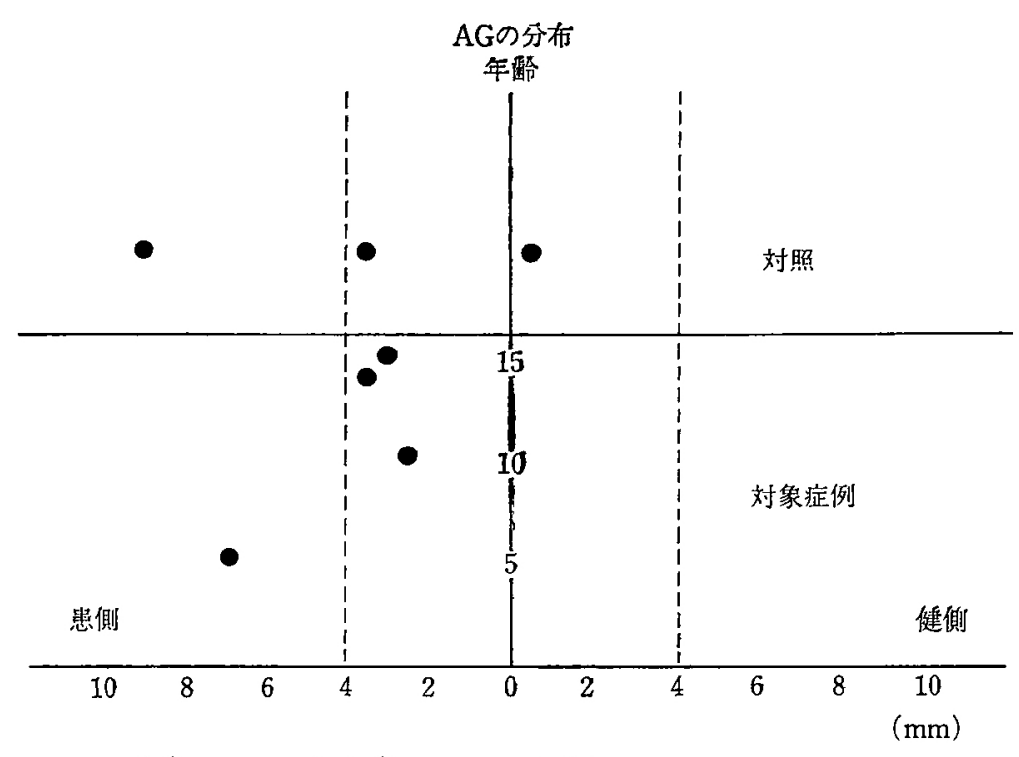
A I型
$\triangle$ II 型
- III型

図 5 正貌頭部X線規格写真分析によるAG の分布

AG 角は, AG と同様吕型のみに設定できた（図 6). AG 角の全体の分布は，健常者に比べてやや狭く，一の 值をとる傾向があった．特に，5歳時手術症例は $-3^{\circ}$ とーの大きな值を示した，対照の开型では AG 角は +0.5であり，ほとんど変化を認めなかった。

ABW 角については, 対象例全体の分布は, 健常者群 に比べてやや広い分布であった（図 7)．Ｉ型とII 型で は，一の值にかたよる傾向がみられた。対照例の而型は 十の值に偏る傾向がみられた。

CAW 角については, 全体として健常者に比べてかな り分布が広く，十の値への偏上りがみられた（図 8). II型の症例 8 と症例 6 はそれぞれ6 $6^{\circ}$ と $4^{\circ}$ を示し，十への 偏よりが大きかった（写真 4, 図9）。刘照症例も十一 偏よる傾向を示した。

\section{2. 側貌頭部 $\mathbf{X}$ 線規格写真による分析}

側貌頭部X線規格写真の分析を行ったのは対象症例 7 例と対照症例 3 例である. 対象症例の場合, I 型の 3 例 中 2 例は Convexity, L1 to occlusal, L1 to mandibular, SNA-SNB difference, U1 to NP, U1 to SN, Gonial angle が平均值上りも大きくなる傾向があった。 この 2 例は, プロフィログラムではほ注同一の鳥貌の傾 向を示した（図10）、I 型扰よびII型の他の症例では上 記 2 例のような共通した特徵は示さなかった。 III 型で は，対象例および対照例ともに同一の傾向を示し，U1 to FH, U1 to SN, Ramus inclination が平均より大 きくなる傾向があり, Convexity と Interincisal は小さ くなる傾向があった。

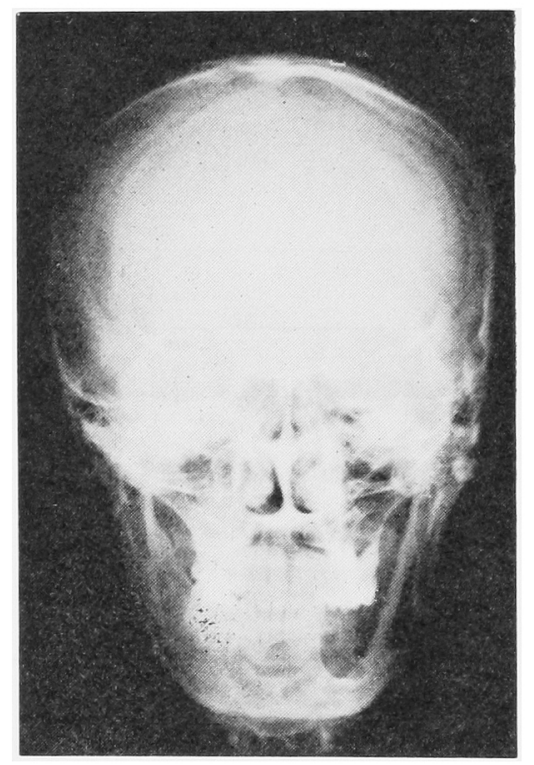

写真 4 症例 8 の得後 10 年の正貌頭部 $\mathrm{X}$ 線規格写真

\section{3. 顎態模型および Occlusogram による咬合につい ての所見}

顋態模型を分析した症例は，対象症 例 5 例（I 型 3 例，II型 2 例) と対照症例 2 例であった。対象症例では I 型の 3 例中 2 例に上領前突, 過蓋咬合, 頼側交叉咬合 の合併がみられ， II型の 2 例中 1 例に開咬がみられた。 また下顎欠損部への上領の㐘の挺出は 5 例中 4 例にみら れ，観察した 5 症例全例に個々の歯牙の歯冠の高さが不 


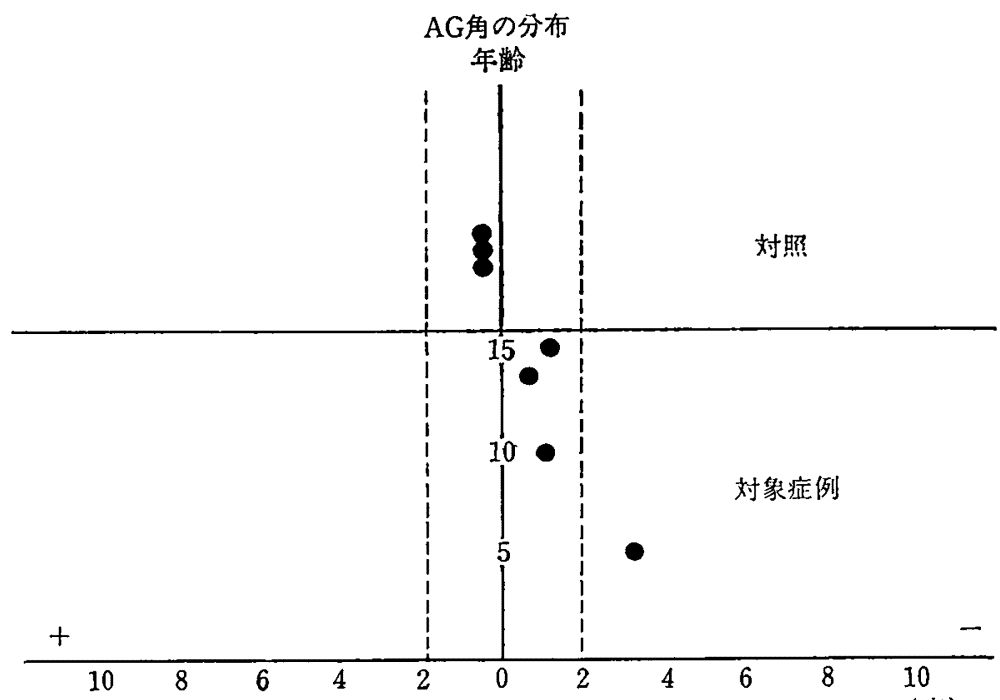
$\Delta$ I 型
$\triangle I I$ 型
III型

図 6 正貌頭部X線規格写真分析による AG 角の分布

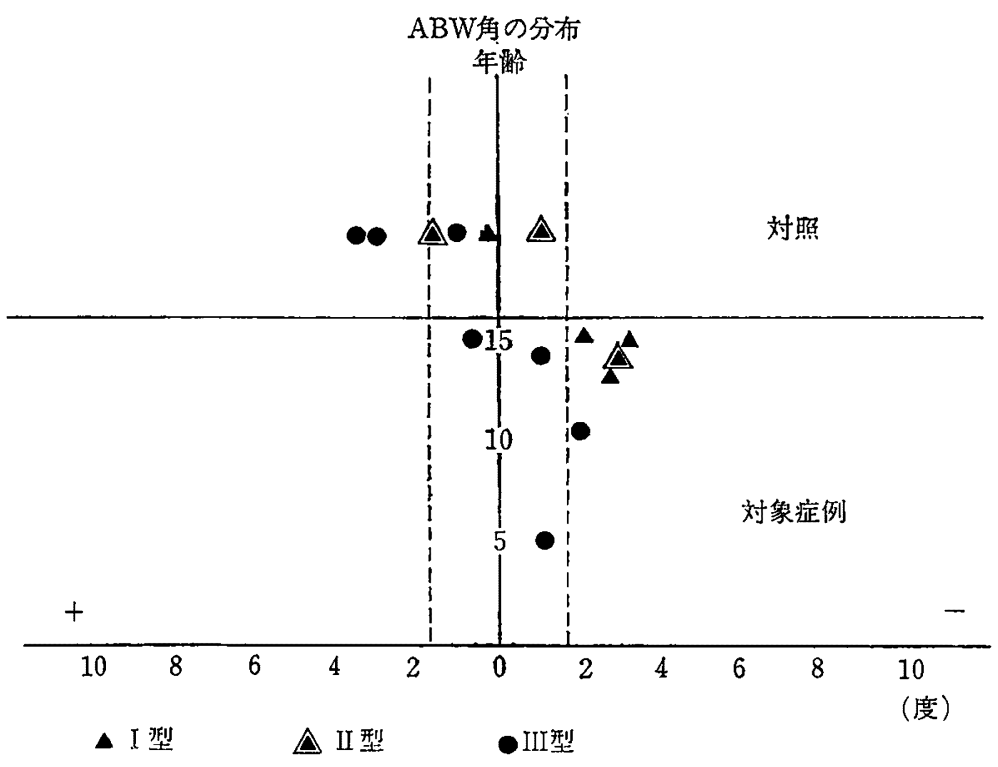

図 7 正貌頭部X線規格写真分析による $\mathrm{ABW}$ 角の分布

揃いとなったための咬合平面の歪みがみられた。

Occlusogram で上下顎歯牙の関係を観察すると，I 型とII 型では，下靧の劣成長，下買歯列が上額歯列より 後退し, しかも患側へ偏位している点, 上下顎の歯の接 触点の減少, 頓側交叉咬合などが特徵的であった（図 11). II 型ではほほぼ正常な咬合状態を示していた。

\section{4. その他の $\mathbf{X}$ 線学的所見}

対象の I 型とII 型の全例に，切離した骨に相当する部 位に骨新生像がみられた。 4 例中 3 例では下影骨体の切 離面から顎関節相当部の間に，橋渡しをするような長い 直線的な新生骨の形成がみられた。他の 1 例（I 型）で は下靧骨体からの新生骨之䫣関節相当部からの新生骨が 途中で途切れていて，2つの不規則な形状の新生骨が形 


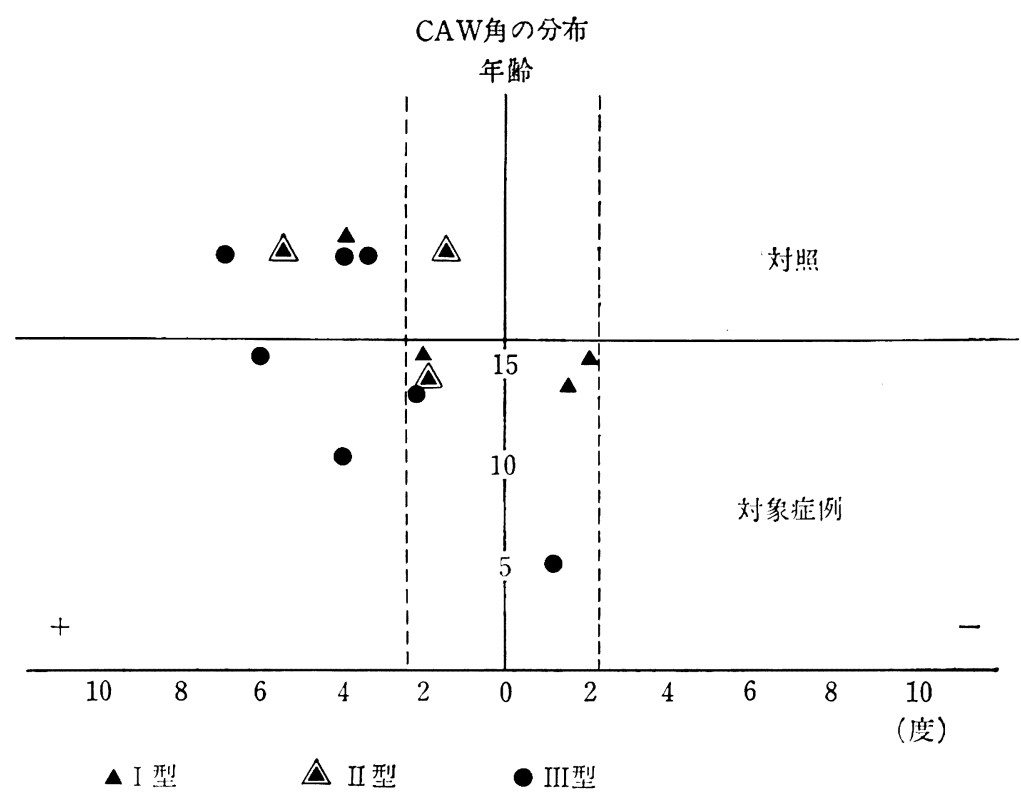

図 8 正貌頭部 X線規格写真分析による CAW 角の分布

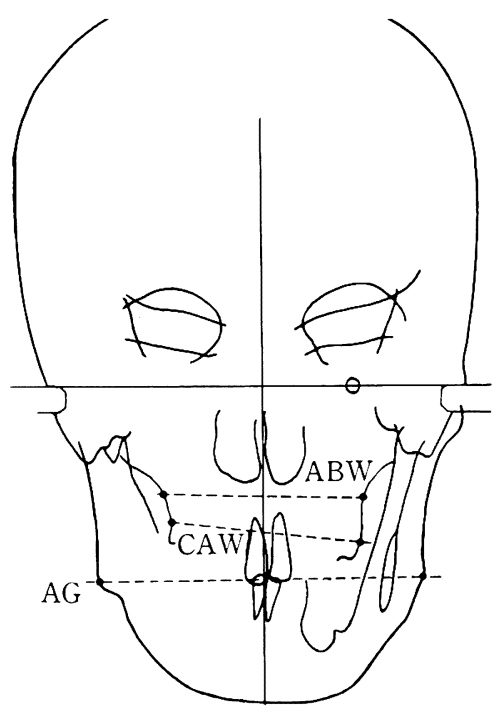

図 9 症例 8 の正貌頭部X線規格写真透写図

成されているのが観察された．対象例の III 型 4 例中 1 例 に, 下顎枝前縁に相当して細長い直線状の新生骨が形成 されていた，他の 3 例でも，大きさは小さいが新生骨と みなされる骨組織が形成されていた，対照手術例では新 生骨の所見はみられなかった。

III型において，患側の下䫇角部の形態の変化が，正貌 および側貌の頭部X線規格写真とオルソパントモグラム で認められた，前後方向と側方方向の両者で, 本来 $\mathrm{S}$ 字
PROFILOGRAM (Male)

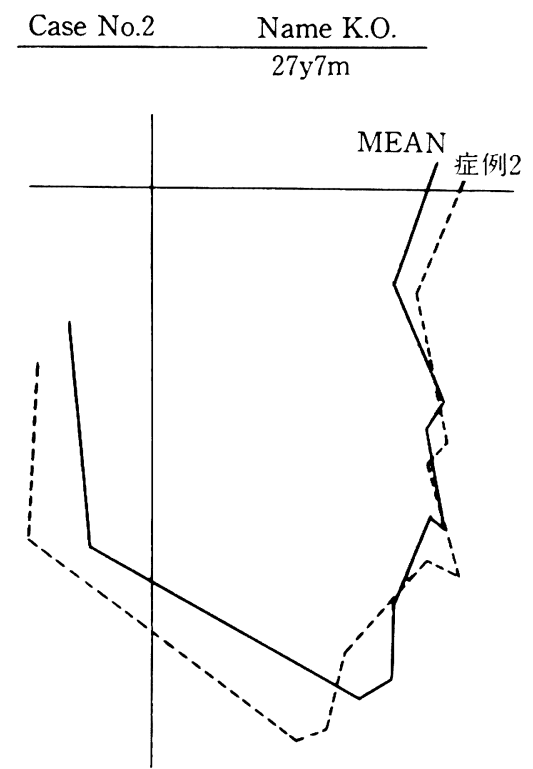

図 10 症例 2 のプロフィログラム

状の複雑なカーブを示す下顎角部が単純な円弧の外形を 示し, 平坦化していた（写真 5 ). 


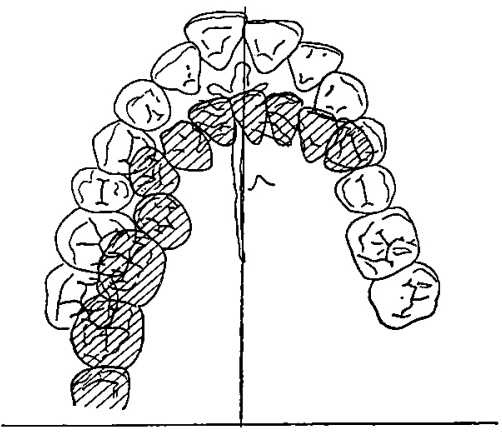

図 11 症例 1 Occlusogram（斜線は下顎の㐘牙）

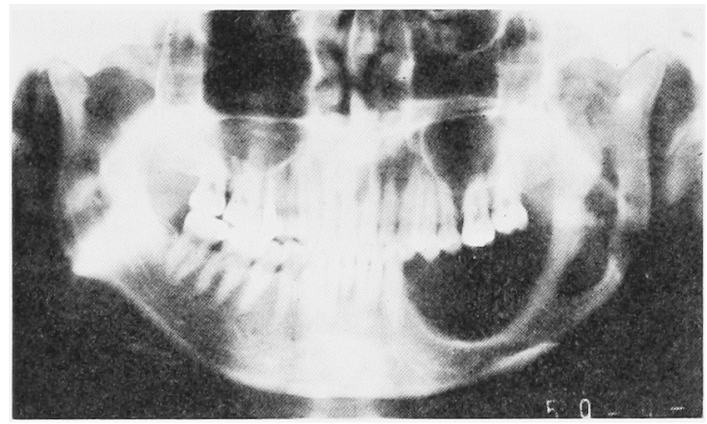

写真 5 症例 8 の術後 10 年のオルソパントモグラム

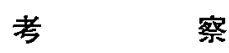

下顎骨の切除に際し，顎骨の欠損による審美的障害， 頞の発育異常などの形態的障害と咀嚼機能低下, 頡運動 の異常などの機能的障害が問題となってくる.これら術 後の障害について, Sarnat ら² は, 若年者に対し下䫇骨 切除術を行った場合, 特に関節突起や下顎枝の切除症例 では，下顎骨の劣成長をきたすが，この変化は，矯正的 にも, 補綴的にも, 外科的にも, 完全に回復させるのが 困難であると述べている，この種の变形は，䫇骨（およ び周囲の軟組織）の笑質欠損によるもののほかに，筋肉 のバランスの滖失とる結びつけて考学られ, Thompson? はすでに1943年に，下頱骨切除による顔面の非対称の問 題を指摘し，筋肉のアンバランスと関連つけて説明して いる，機能障害の面については，近年 mandibular kinesiography，笳電計などの霆子機器の発達により，下䪽 骨切除患者の咬合機能などの分析が行われるようになっ だ 11)

しかしながら，小昌期における下顎骨切除後の顎顔面 の変形についての詳細な㭘討は，ほとんど行われておら ず，わずかに名倉ら ${ }^{12)}$ が顔貌所見と下䫑の偏位に言及し ているにすぎない，著者らは，今回，小罗期に下顎骨切 除手術を行った症例に対して, 䫟発育完了後の頭部X線
規格写真の分析などにより，顎顔面の変形について檢討 を行った。

頭部X線規格写真のらち，側貌像の分析については, すでに数多くの研究がなされ, 現在では, 臨床上不可欠 の分析手段として臨床応用がなされている，一方，正貌 像は臨床的応用をはばも各種の問題点が存在するといわ れており，それは次の 3 点にまとめられる(3).

1. 正確な再現性のある規格写真の撮影についての問 題

2. 基準点の設定についての問題

3. 分析の基準となる正中線の設定についての問題

これら問題の解決についての種々の試みがなされてい る. 1 の問題点については，完全解決とまではいえない が, 眼点指示器を使用して Frankfort 平面に平行に撮影 することが勧められ，本研究に颃いては健常者のデータ にばらつきが少ないことから，特に再現性について性 題を認めていない，20問題点については本邦に和いて は中後》，本橋ら ${ }^{14}$ の研究報告があるが，いずれの方法 る明らかな優劣はないと思われる，3の問題点について は, 現在，中後の設定した PO 垂線と，Sassouni ${ }^{15)}$, 近 藤3) の設定した Lo-Lo' 線の垂線との 2 種類が，一般に 推奖されている. 本研究に和いては, 角度的基準として 重要な Frankfort 平面に関連性を持っていることと，そ の簡便性の面から，中後のPO 垂線を正中線として採 用した。

中後の方法では，主に左右同名点間の距離が分析の指 標とされていた。 しかし，本研究で行う正貌頭部X線規 格写真分析の目的は，顔面の非対称を検索することにあ るため，著者らは左右の計測值の差によって分析するの が妥当であると考えた，また，近藤3゙の方法では，左右 の非刘称性をみる場合, 雨側計測点の中点の正中線から のず机を想定して分析を行っている，著者らは，永井 $5^{16)}$ ，清水 ${ }^{17)}$ と同様，元来ある程度非対称的である顔面 骨格について，左右の 2 基準点の中点を想定することは 意味がないと考えて，左右差そのものを分析值とした。

著者らは，あらたに $\mathrm{ABW}$ 角， CAW 角， AG 角を 考案して，枵骨の非対称性のらち，上下方向の西みを検 索しようと試みた。この新しい分析項目は，この研究に おいては，有力な分析手段となり，実用的な計测項目て あることがわかり，今後に和ける影顔面の変形の計測は もちろん，治療上に扎いても有用な方法と考えられた。

近藤引は，正貌頭部X線規格写真の分析に批いての左 右差に基ついた基礎的資料を報告している，そこで，本 研究の健常者群の資料と，近藤の資料とを比較してみた (表 5)，著者らの AG における標準偏盖は4.14でか り，近藤の7.50に対し非常に小さく，逆に，著者らの L 1 とU 1 の標準偏差は2.05と1.92であり，近藤の0.40 と0.18に比べて，やや大きな值であった，近藤の被験者 の選択条件では，上下䅡の正中が一致することがあげら 
表 5 健常者対照群の資料と近藤の資料との比較

\begin{tabular}{l|c|c|c|c|c|c}
\hline \multicolumn{3}{c|}{ (近藤) $\rightarrow$ 中点の正中からのずれ } & \multicolumn{3}{|c}{ (著者ら) $\rightarrow$ 左右差 } \\
\hline & 平 均 & $\begin{array}{c}\text { 標淮偏差 } \\
\text { (S.D.) }\end{array}$ & S.D. $\times 2$ & & 平均 & $\begin{array}{c}\text { 標隻偏差 } \\
\text { (S.D.) }\end{array}$ \\
\hline Go & +0.10 & 3.75 & 7.50 & AG & +0.79 & 4.14 \\
L 1 & -0.10 & 0.40 & - & L 1 & +0.65 & 2.05 \\
Mx & 0.00 & 1.15 & 2.30 & (ABW) & +0.17 & 2.66 \\
CMo & -0.19 & 1.31 & 2.62 & CAW & +0.50 & 3.28 \\
U 1 & +0.03 & 0.18 & - & U 1 & +0.50 & 1.92 \\
\hline
\end{tabular}

注）L 1 とU 1 では，両者はそのまま比較できる，

れており，この条件の影響で近藤の資料では L $1, \mathrm{U} 1$ の標準偏差が小さいと考えられた，著者らは，手術の影 響を検討する目的から，特にこの条件を対照群に求めな かった.

以下，検索項目別に手術方法による変形の特徵につい て考察する.

L 1 については対象例の関節離断症例のらち，2 種類 の手術方法間の相違が明らかになった，下顎下縁を残し たII 型では L 1 の偏位は小さく，乙かも健側のみに偏位 していた。一方，下縁を残さないＩ型ではＬ１の偏位は 非常に大きく，患側のみに偏位していた。このL 1 の高 度の偏位は残存下顎骨の患側への回転と傾斜による位置 の変化が主要因と考えられ，これは同様な対照手術症例 の結果とも一致していた. すなわち, 解剖学的に考えて みると下顎骨離断術による下顎の偏位は, 残存下顎骨が 内・外側翼突筋, 顎二腹筋前腹などの咀嚼筋群により切 除側に率引され，下買骨正中部は切除側に偏位して，全 体としては，健側下顎頭を中心として回転が生じる現象 であると考えられる。しかし，下顎下縁を下顎角付近ま で長く残した場合この変化は少なく，おそらく咬筋，内 側翼突筋が一部残り，下㴿骨の位置を規定している筋群 のハラランスが良く保たれ，回転と傾斜とをある程度防止 しているためと推察される。部分切除症例の III 型では, L 1 の偏位はほとんどない.この理由としては,この手 術法が下顎骨の位置を変化させていないことから理解さ れる.

U 1 の偏位は総じて，L 1 に比べて小さかった。 しか し, U 1 の分析結果からも, II 型の偏位は I 型とは反対 で, わずかではあるが健側への偏位であることが示され た.すなわち，U 1 はL 1 の偏位と同側へ偏位する傾向 を示しており，下顎骨への手術侵襲が，上顎にあるU 1 の位直をも変化させらる可能性が示唆された。

AG についてみると， II 型では，L 1 の項目で示した ように，下顎前歯部での明らかな偏位はみられなかった が，患側の $\mathrm{AG}$ 横径より健側の $\mathrm{AG}$ 横径の方が明ら かに大きかった.これは患側の $\mathrm{AG}$ 下顎角部の成長が 抑制されて, 患側の AG 横径が健側に比べ相対的に小さ
くなったものと考えられる.

このような下顎骨への手術的侵襲が下罰角部の成長抑 制を伴ら現象については，実験的な研究報告がある。久 保田は ${ }^{18)}$, 動物実験において犬の咬筋の切除を行うと, 成長後の罘角突起 (angular process) は内側へ陥入し, 顎角前切痕 (antegonial notch) は浅くなり，顎角部の 形態変化が起こることを示した． Avis ${ }^{19)}$ は， ラットの 咬筋と内側翼突筋の両者を切除すると, 顎角突起が全く 形成されなくなると報告している。一方, Arena ${ }^{2}$ はラッ トの下顎骨体部を切除したが，手術部位の違いよりも外 科的侵襲それ自体が成長を抑制する最大の因子であると 結論している.

このように患側の AG 幅径が減少していることは咬 筋と内側翼突笳の切離による影響が表れて，患側の下顎 角部の劣成長を生じたためと説明できる。

AG 角については, 部分切除症例において, 患側の $\mathrm{AG}$ が健側の AG より Frankfort 平面に向かって高い 位置になりやすい傾向が示され，患側の下顎枝の長さの 減少が示された。これは，手術の影響による患側の下顎 枝の垂直方向における劣成長を示していると思われる．

ABW 角については, 対象症例の I 型, II 型および II 型を通じて，患側の $\mathrm{ABW}$ の方が，Frankfort 平面に向 かって高い位置になりやすく，反対に，対照症例におい ては，患側の $\mathrm{ABW}$ が低い位置になりやすいことが示 された， $\mathrm{ABW}$ は，作図上の点であり，MHW（最大頭 幅点）と CAW との位置関係と上顎骨基底部の 外形に より制約を受ける。対象症例では患側の上䫇骨基底部が 通常より上方に位置しやすく，上顎骨歯槽突起の側方方 向への成長の減少を示しているが，これは，上靧臼歯が 早期に挺出するために，根尖周囲の歯槽突起の形態が変 化するためと思われる，対照のIII型では，上罘骨基底部 が下方に位置しやすいことが示され，上顎臼歯の拠出と の関連が示唆される。

CAW 角については, 対象症例および対照症例ともに I 型, II 型および正型を通じて，患側の CAW の方が 低い位䏣にある。これは患側の上顎骨粜槽突起が下方に 位置していることを示す，つまり，患側の上顎歯牙が挺 
出していることを意味している.

側貌頭部X線規格写真による分析についてみると，対 象症例の I 型は, 同様の側貌パターンを示し（症例 1 , 症例 2), 上顎前突, 上下䅡前歯の唇側傾斜, 下㴿角部の 開大, 下顎枝の後方への回転がみられ, Angle 分類 II 級 1 類に類似した所見であった．これは基本的には，下顎 骨全体の劣成長と, 図11の Occlusogram に示されるよ らに，下顎歯列が後退していることによると考えられ る. III 型では対象および対照症例の両者ともに上䇣前歯 の唇側傾斜，下顎枝の前方への回転がみられ，I 型およ びII 型に比べ，下顎骨の劣成長が少なく，比較的良好な 顔貌所見を示していた。

咬合所見については，I 型，II 型および息型を通じ て，咬合異常が高頻度に認められた。この理由として は, 下顎の劣成長や咬合機能のアンバランスが咬合異常 を起こす大きな要因となっているためと思われる，特に 手術法の差異による影響は大きく，I型およびII 型の関 節離断症例では，交叉咬合や煩側交叉咬合など，下顎骨 の煩舌方向での位置的変化を示す咬合異常が多かったの に対し， II 型の部分切除症例では，開咬や凿生なと，性 質の異なった咬合異常を示した.

5 歳時部分切除症例以外のすべてに，下顎霜牙欠損へ の上䫟臼歯の挺出が見られ，その結果，咬合平面の歪み が生じていた. 5 歳時に $\overline{6 \uparrow 1}$ の部分切除術を受けた症 例 5 では高度の開咬が生じていたが，これは下顎前歯部 の久損による舌の悪習癖がその一因と推測された。

その他のX線学的所見としては, 対象症例の I 型およ び II 型の全例と II 型の一部で, 㖽骨欠損部に, 新生骨の 形成が観察された 新生骨の形成には年战的要因が大き く，15歳以下では新生骨の形成が良好なように思われ た21).

III 型の部分切除症例では, 形態変化として, 下顎角部 の平坦化が観察された。この原因としては術前に生じた 腫瘍の増殖に伴う反応性の下顎角部の膨隆があったこ と, 手術により菲薄となった下顎角部に新生骨の添加が 起こったことなどのほかに，筋の切断や歯の欠損などに 伴って下顎角部の成長発育の機能的因子が障害されたこ とが考えられた。

正貌頭部X線規格写真によって得られた結果を総合す ると, 下顎骨切除術を行った年龄が低いほど，顎顔面に 生じる左右非対称は大きかった。これは, 顎発育の思春 期性スバートが，ほとんどの場合15歳までに終わる ${ }^{22)}$ と いら報告からも理解されることである. L 1， U 1， AG，AG 角のそれぞれにおいて，年龄が低い症例ほど， 偏位の程度は大きかった。しかし, CAW 角では, 年踰 が高いほと，偏位の程度は大きく，また开型の ABW 角 の偏位の傾向は手術年齡が上がってくるにしたがって偏 位の方向が逆転するなど, 上記の傾向との違いがみられ た.これは, $\mathrm{ABW}$ 角と $\mathrm{CAW}$ 角には, 手術侵竩が間
接的にしか影響せず，上顎歯牙の挺出が，この変化の主 要な要因であるためと推察された.

その他の所見をみても，やはり手術時年战が低いほど 顎の変形は大きいといら結果が得られた。 また頭部 $\mathrm{X}$ 線 側貌規格写真の分析所見や咬合所見においても，年龄が 低いほど異常所見の出現が多くなる傾向がみられた。 し かし，上顫牙の挺出の程度や下顎角部の平坦化の程度 などは，年龄による相違が明らかではなかった。

下顠骨切除術の目的が腫淘を完全に切除することにあ ることを考えれば，ある程度の変形はやむを得ないこと である．しかし現在でも小睍の術後変形に対する治療法 は，確実なものがないので，根治性を損なわない限り， できるだけ手術時に変形を予防するような治療法が望ま れる.

顎の変形を予防する方法として，上野は23)下䫚下縁お よび下顎枝後縁を厚さ $3 \mathrm{~mm}$ 以上残しらるならば，可能 なかきり離断術はせずに部分切除術にとどめ，下䫑の形 態を保存するべきたと主張している．本研究ではこの意 見をさらにすすめて，関節離断術を行った場合です，可

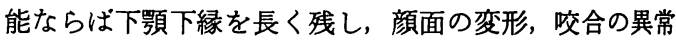
を最小限にとどめることを推奖したい.

また, Desjardins ${ }^{24)}$ は補緅学的立場から, 術直後の䕘 間固定とすみやかなリハビリテーションとしての補緅処 置を勧めており，われわれも同様の見解である。しか し，小児期の永久歯萌出完了以前では，箩間固定が困難 なこともあり，FKO タイプの固定装置を用いるのも一 方法だと考えられる。 また，術後の義歯についても，対 合雪の挺出防止などの面からも早期に装着すべきであ る.

以上を要約すると，顎発育期にある小睍においては， 手術の切除範囲は根治珄を損なわない限り小さくし，可 能な限り関節頭離断術を避け下顎の辺縁を残す部分切除 術にとどめるのが良いと考えられた。 また，やむなく関 節離断を行う場合でも可能な限り下䫇下縁を残すことが 望ましい，さらに，襄胞性エナメル上皮腫などの場合に は, 著者のうちの佐藤 ${ }^{25)}$ が推奖するように, 一次治療と しての開空療法を行い, 病変の縮小を計った後, 部分切 除術を行らなど手術範囲の縮小化と, 手術時期の延長を 考虑した治療方法を行らのが良いと考えた。

\section{結 論}

当科において，下顠骨切除術を行った小児患者 8 例に ついて, 正貌頭部X線規格写真の分析を中心に, 顎顔面 の変形について対照の成人手術例および非手術例と比較 検討を行い, 以下の結論が得られた.

1. 下顎骨切除術後の顎顔面の 変形として, 上下䫑正 中の偏位, 下顎枝部の劣成長, 上顎田歯の挺出, 残存下 顎骨の回転と傾斜, 咬合異常, 下顎角の平坦化, などが 
生じていた.

2. 手術方法の違いによる, 顎顔面の変形の相違につ いては, 部分切除症例では, 罰顔面の変形は比較的軽度 であったが，関節離断症例では変形は高度であった，し かし，下顎下縁を下箩角部をで保存しえた症例では，通 常の骨体部での離断症例に比べて変形は少なかった。

3. 手術方法が同じでも, 手術時年龄が低いほど, 顎 顔面の変形は大きかった.

4. 以上より小児期の手術範囲は根治性を損なわない 限り小さくし，下縁の一部で残せるものは残し，手術侵 襲のより少ない手術法を採用することが望まれる。

本論文の要旨は第37回日本口腔科学会総会(1983年 4 月2日，大阪）に扒いて発表した。

\section{引用文 献}

1）中後忠男, 石沢命久, 他 - 頭部X線規格正貌写 真分析法に関する正中線の決定について。矯 菌誌 20: 151-157 1961.

2) 中後忠男: 頭部 $X$ 線規格写真法による日本人成 人男子の脳頭蓋・顔面頭蓋の形態学的研究. 日 矯掬誌 23: 63-74 1964.

3）近藤悦子：日本人成人男女についての頭部 X線 規格正貌写真法に上る検討。日矯菌誌 31 : 117-136 1972.

4）飯塚哲夫, 石川富士郎：頭部X線規格写真に上 る症例分析法の基準值について。 日矯菌誌 16 : 4-12 1957.

5) Marcotte, M.R.: The use of the occluss ogram in planning orthodontic treatment. Amer J Orthodont 69: 655-667 1976.

6) Sarnat, B.G. and Robinson, I.B.: Surgery of the Mandible-Some clinical and experimental considerations. Plast reconstr surg 17: 27-57 1956.

7) Thompson, J.R.: Asymmetry of the face. J Am Dent Assoc 30: 1859-1871 1943.

8) Endo, N.: Studies on masticatory functions in patients with surgical mandibular reconstruction. Oral surg 34: 390-406 1972.

9）紊藤 力：下顎骨切除患者の䫇連動機能に関寸 る研究。莯科学報 76: 441-482 1976.

10）高橋悠夫：下顎骨切除患者の罰機能に関する研 究. 広大蔽学 15：285-300 1983.
11）谷本啓二, 定成 隆, 他：X線映画による下顎 骨切除患者の顎運動の観察. 口科誌 33：1921991984.

12）名倉英明, 兽田忠雄, 他: 下顎切除症例の遠隔 成樍について一（第 1 報）成長期患者について の調査結果. 日外誌 $25: 833-8411979$.

13）森主宣延, アンヘル亀田, 他: 頭部 X線正貌規 格写真に打ける正中線の設定について。专 学 48: 586-589 1974.

14）本橋康助, 龟田晃, 他: 頭部 X線規格正貌写 真の研究にあたって考愿すべき 2,3 の事項に ついて。 日矯隧誌 31: 105-116 1972.

15) Sassouni, V.: Diagnosis and the treatment plan via roentgenographic cephalometry. Amer J Orthodont 44: 433-463 1958.

16）永井緟, 辻 忠良, 他: 下顎正中破裂の 1 例 について。科誌 16: 505-512 1967.

17）清水義之：正貌頭部X線規格写真法による片側 性完全唇顎口蓋裂者の䫕顔面頭蓋の形態学的検 討一IVA以後の女子について. 九州歯会誌 29: 788-799 1976.

18）久保田康耶：顎関節侵巃の顔面骨発育に及ぼす 影鄉に関する実験的研究。口病誌 $27: 368-391$ 1960.

19) Avis, V.: The significance of the Angle of the mandible-An experimental and comparative study. Am J Phys Anthropol 19: 55-61 1961.

20) Arena, S.A.: Resection of the mandibular body and its effect on mandibular growth. Amer J Orthodont 76: 218-222 1979.

21）西嶋克巳, 岸 幹二, 他: 下顎骨を含めた下顎 骨片側離断術後の骨新生について。 日外誌 21: 491-497 1975.

22）日置 誠：長期観察学童における“からだ”の 成長と顔の成長との関係について。 日矯料誌 25: 1-30 1966.

23）上野正：頷骨手術の要点一 2 一特にエナィル 上皮腫手術について。蔯界展望 30：1007-1011 1967.

24) Desjardins, R.P.: Occlusal considerations for the partial mandibulectomy patient. J Prosthet Dent 41:308-315 1979.

25）佐藤建夫：エナメル上皮腫の臨床病理学的研究 一特開空療法汇ついて。日病誌 50：114-147 1983. 